\title{
Analysis of HIV/AIDS Reports in Turkey from Disaster Management Perspective
}

\author{
Nahsan $K A Y A^{l}$
}

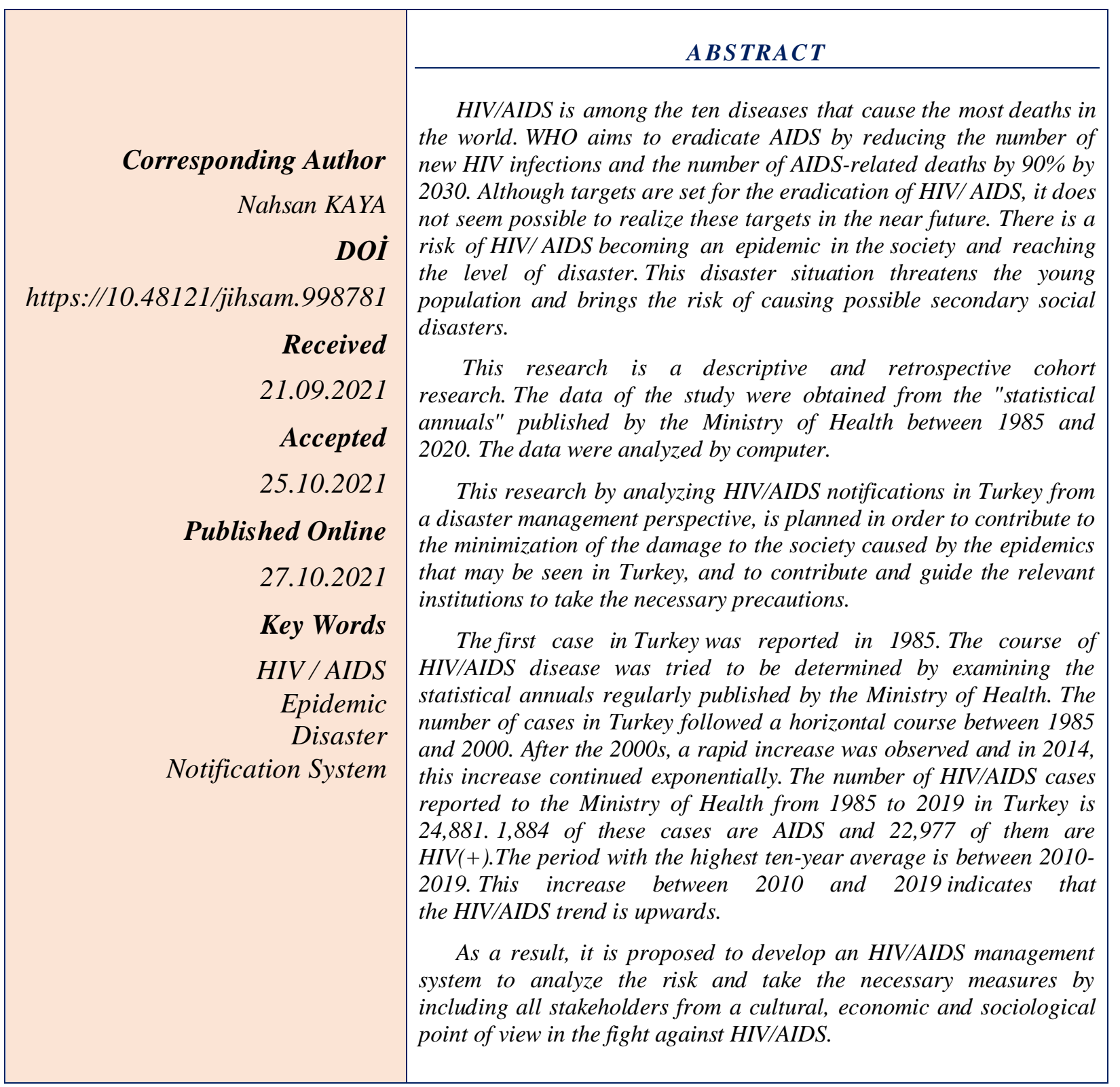

\footnotetext{
${ }^{1}$ Lecturer, Medical Imaging Techniques, Simav Vocational School of Health Services, Kütahya Health Sciences University, TR-43500 Kütahya, Turkey. nahsankaya0229@ gmail.com / Orcid Number: https://orcid.org/0000-0003-4933-2738
} 
There is no definitive cure for The Acquired Immune Deficiency Syndrome (AIDS). The drugs used aim to increase the lifespan and life quality of the infected individuals. It brings along problems such as social, economic, human rights and discrimination in society. AIDS is an important infectious disease that should be studied from the point of view of disaster management, since the rapid increase in HIV/AIDS case reports in the world and the risk of reaching unexpected dimensions.

The Acquired Immune Deficiency Syndrome (AIDS) epidemic, which is caused by the immunodeficiency virus (HIV), has caused the death of approximately 39 million people since the first case (1981). The HIV virus, which seems to have passed from monkeys to humans, was first detected in Congo in 1959, but AIDS was diagnosed and named in 1981. HIV is thought to be transmitted to humans as a result of interspecies transfer of monkey immunodeficiency viruses. Although the first reported cases of AIDS were among homosexuals in the United States in the early 1980s, it is estimated that it probably first infected humans in the late 1940s. Today, the HIV-1 virus is found all over the world, but HIV-2 is mostly found in West Africa and is considered less deadly than HIV-1. There is still no solution to the epidemic, which has caused approximately 70 million cases and 40 million deaths in the last 40 years. Approximately 980,000 new cases were reported in 2017. he fact that 180 thousand of these cases are children, is an indication that the goal of eliminating new HIV infections among children in 2018 was not succeeded. Although new HIV infections have decreased by $40 \%$ since the peak in 1998; in 2020, 1.5 million people were newly infected with HIV. The number of people living with HIV rose to 37.7 million, and 680,000 people died from HIV-related causes. About half of the cases were in Africa, and more than half of the deaths were in three countries (Mozambique, South Africa and the United Republic of Tanzania). The Middle East and North Africa has the lowest HIV prevalence $(0.1 \%$ among adults aged 15-49 years) (WHO, 2021c).

In recent years, epidemics have been observed in some countries. Eastern Europe and Central Asia are the only regions in the world where the HIV epidemic continues to increase rapidly. There has been a $30 \%$ increase in new HIV infections since 2010. It is seen that the epidemic is especially concentrated among intravenous drug users. The lack of harm reduction services, homosexuals, intravenous drug users and low condom use have increased the spread of the disease. Stigma, discrimination and criminalization are the main reasons for the spread of HIV, especially in Eastern Europe and Central Asia: most people living with HIV and AIDS suffer from stigma. The consequences of stigma and discrimination are profound. People are more afraid of unfair sexual behavior (sin), blame, shame, rejection and stigma than of dying as a result of HIV/AIDS. Many women fear discrimination, violence and even murder if they are found to be infected with HIV. For this reason, many people living with HIV and AIDS do not get tested because they fear of the results. People hide that they are sick because they are stigmatized as "immoral" and cause the spread of a deadly disease. Also, sexual relations or drug use are often taboo. That is why society is vulnerable to the silent spread of HIV. Women are often accused of spreading sexually transmitted infections (STIs), including HIV, even if they are infected by their husbands or partners. Mother-to-child transmission can be prevented by antiretroviral (ARV) prophylaxis and not breastfeeding (WHO, 2021c).

While life expectancy has remained relatively high in high-income countries, life expectancy has decreased significantly in most low- and middleincome countries with the burden of HIV and AIDS (Merson et al. 2011).

Acquired Immunodeficiency Syndrome (AIDS) is a serious, life-threatening disease caused by the human immunodeficiency virus (HIV). HIV can affect the T lymphocyte cells of the human immune system and leave these cells vulnerable to possible infections and diseases in the body, leading to various opportunistic infections and death (Web 1, 2021).

Even though there is a $59 \%$ decrease in deaths from HIV/AIDS from 2000 to 2019, HIV/AIDS is still one of the ten infectious diseases that cause the most deaths (WHO, 2021a).

People with HIV (+) make up about $0.5 \%$ of the world's population (WHO, 2020). In virusinduced pandemics, those with HIV+ are considered as a risk group. In the H1N1 influenza pandemic (2009-2010), it has been reported that there is a higher rate of transmission and illness among HIV+ persons ( Sheth at al., 2011). It has been noted that HIV infection does not cause an increase in the severity of the disease in SARS and MERS epidemics (Al Omari at al., 2019; Moni and Lion, 2014). It is stated that with the Covid-19 pandemic affecting the world, the risk of causing negative consequences may increase in people with HIV-related immune dysfunction (Williamson at al., 2020). Studies have revealed that the risk of dying from COVID-19 among people with HIV is twice as high (Web 2, 2021). However, among the studies conducted, there are also studies stating that the Covid-19 pandemic does not affect individuals with controlled HIV infection more negatively than other individuals. 
The World Health Organization (WHO) HIV 2016-2021 global health sector strategy aims to reduce the number of new HIV infection cases and AIDSrelated deaths below 500,000 by 2020 . In the AIDS 2021-2026 global health sector strategy, it is aimed that the number of new HIV infections will fall below 370,000 by 2025 , and AIDS-related deaths will fall below 250,000 by 2025 . The 2030 goal is to reduce both the number of new HIV infections and the number of AIDS-related deaths by $90 \%$. As the WHO 2030 sustainable development goal, it aims to eradicate the HIV epidemic in all countries (WHO, 2021b).

It is estimated that there are 38 million people living with HIV worldwide in 2019. About 1.7 million people are infected with HIV. In the same year, approximately 690,000 people died due to HIV-related diseases. These data reveal that the goals set by WHO have not been achieved.

The fact that there is no definitive treatment method yet, the drugs used aim to increase the life expectancy and quality of life of the infected individual and the fact that it brings together problems such as social, economic, human rights and discrimination in society causes AIDS to reach unexpected dimensions. This shows that HIV/AIDS will continue to be one of the major social, economic and health problems in the world.

HIV/AIDS cases were first reported in Turkey in 1985. Factors such as the young population of the country, the lack of sufficient information about sexually transmitted diseases, improved tourism opportunities, the high number of Turkish population abroad have increased the number of HIV/AIDS cases in Turkey (Akın, 2007).

In line with the notification and notification system of communicable diseases, HIV/AIDS has been added to the notifiable diseases category and infectionspecific surveillance has been initiated since 1994. HIV/AIDS surveillance is important to identify the need for HIV/AIDS intervention programs, allocate resources during planning, monitor the effectiveness of prevention and controll measures and response strategies, identify target population groups at high risk, lead studies on risk factors for the spread of the virus and progression to AIDS. Within the scope of the developed Turkey HIV/AIDS Control Program, reducing the number of HIV/AIDS new cases and deaths due to infection, improving the capacity of health services for HIV/AIDS, and preventing discrimination and violations of privacy against individuals living with HIV have been determined as the main objectives (T.R. Ministry of Health, 2019).

By combining surveillance data in one center, it will be possible to prevent possible outbreaks by determining the epidemiology and risk points of infection. It should not be forgotten that surveillance studies are also a source of motivation in health studies. However, diseases such as AIDS, which started in developed countries and spread rapidly to other countries, should be followed with special attention before they reach the epidemic level in the society. The importance given to the surveillance of HIV infection will make it easier to detect the changes in its spread early and to take it under control. Therefore, WHO recommends the use of a second generation surveillance system in the surveillance of HIV infections. The purpose of this type of surveillance, which is a mixed system is;

- To make sense of trends for future periods

- Directing studies to groups at high risk of infection

- Identifying behaviors that will facilitate the spread of infection

- Effective use of surveillance data in planning

This system allows surveillance to be carried out on relevant people or groups representing the community and uses it as a method of obtaining data (Güler and Akın, 2006).

However, the surveillance system, which is the most important way of combating infectious diseases, cannot function properly due to not believing in its necessity in case reporting steps, seeing it as an increase in workload, political obstacles or drudgery (Kaya and Şahinöz, 2021) .

The aim of the research is to analyze the number of reported HIV/AIDS cases in Turkey from the perspective of disaster management and to contribute and goide the minimization of the damage caused by the epidemics in the society and to take the necessary precautions.

\section{MATERIALS AND METHODS}

This study is a descriptive and retrospective cohort study. The data of the study were obtained from the statistical annuals published regularly by the Ministry of Health (between 1985 and 2019) by the registry scanning method. The ethics committee permission was not obtained because it was not required.
This study was carried out between 09.07.202117.09.2021. In this study, the number of cases of HIV/AIDS disease, incidence rates (number of cases proportional to the population), case averages and incidence rates for each decade were calculated. Obtained HIV/AIDS data are presented in 
groups in tabular form. Graphs have been drawn to

make the data better understandable.

\section{RESULTS}

When the health statistics annuals published in Turkey are examined it is seen thatonly the number of AIDS cases and the incidence rate are published. There is no information about the age, gender, occupation, educational status, travel history, source of contamination, place of residence, treatment status, death and other characteristics of the cases. In addition, the fact that the number of HIV+ cases is not given in the statistical annuals published after 2010 also causes difficulties in determining the course of the disease. The total number of cases (new+old) in the country is unknown. Due to this lack of data, it is not possible to conduct a risk analysis for the country and society.

Table 1 shows the distribution by years and 10year averages of a total of 24,881 HIV/AIDS cases reported by the Ministry of Health in all statistical annuals.

Table 1. Number of New HIV/AIDS Cases Reported Between 1985 and 2019 and Ten-Year Averages.

\begin{tabular}{|c|c|c|c|c|c|c|c|}
\hline Years & AIDS & HIV & Total & Years & AIDS & HIV & Total \\
\hline & & & & 2000 & 45 & 123 & \\
\hline & & & & 2001 & 45 & 145 & \\
\hline & & & & 2002 & 43 & 144 & \\
\hline & & & & 2003 & 47 & 142 & \\
\hline & & & & 2004 & 60 & 183 & \\
\hline 1985 & 3 & 0 & & 2005 & 48 & 262 & \\
\hline 1986 & 1 & 2 & & 2006 & 46 & 269 & \\
\hline 1987 & 9 & 35 & & 2007 & 25 & 365 & \\
\hline 1988 & 11 & 22 & & 2008 & 55 & 406 & \\
\hline 1989 & 11 & 25 & & 2009 & 69 & 468 & \\
\hline Average & 7 & 17 & & Average & 48 & 251 & \\
\hline 1990 & 13 & 24 & & 2010 & 73 & 539 & \\
\hline 1991 & 24 & 30 & & 2011 & 80 & 676 & \\
\hline 1992 & 32 & 41 & & 2012 & 97 & 997 & \\
\hline 1993 & 34 & 50 & & 2013 & 101 & 1315 & \\
\hline 1994 & 37 & 50 & & 2014 & 131 & 1917 & \\
\hline 1995 & 28 & 60 & & 2015 & 122 & 2216 & \\
\hline 1996 & 35 & 98 & & 2016 & 105 & 2567 & \\
\hline 1997 & 38 & 101 & & 2017 & 125 & 3044 & \\
\hline 1998 & 42 & 84 & & 2018 & 108 & 3248 & \\
\hline 1999 & 29 & 100 & & 2019 & 112 & 3229 & \\
\hline Average & 31 & 64 & & Average & 93 & 1884 & \\
\hline \multicolumn{5}{|c|}{ Overall Total } & 1884 & 22977 & \\
\hline \multicolumn{5}{|c|}{ Total Average } & 45 & 554 & \\
\hline
\end{tabular}

The number of HIV/AIDS cases reported to the Ministry of Health from 1985 to 2019 in Turkey is 24,881. Of these cases, 1,884 are AIDS, and 22,977 are HIV (+). The period with the highest ten-year average (average of 93 cases) is between 20102019. The trend between 2010 and 2019 is upwards. In terms of disaster management, this trend should be evaluated and AIDS should be fought effectively.

For the last 20 years, 5-year HIV/AIDS Strategic Plans have been prepared in Turkey. However, the increasing number of new cases suggests that this plan is insufficient in the action phase. 


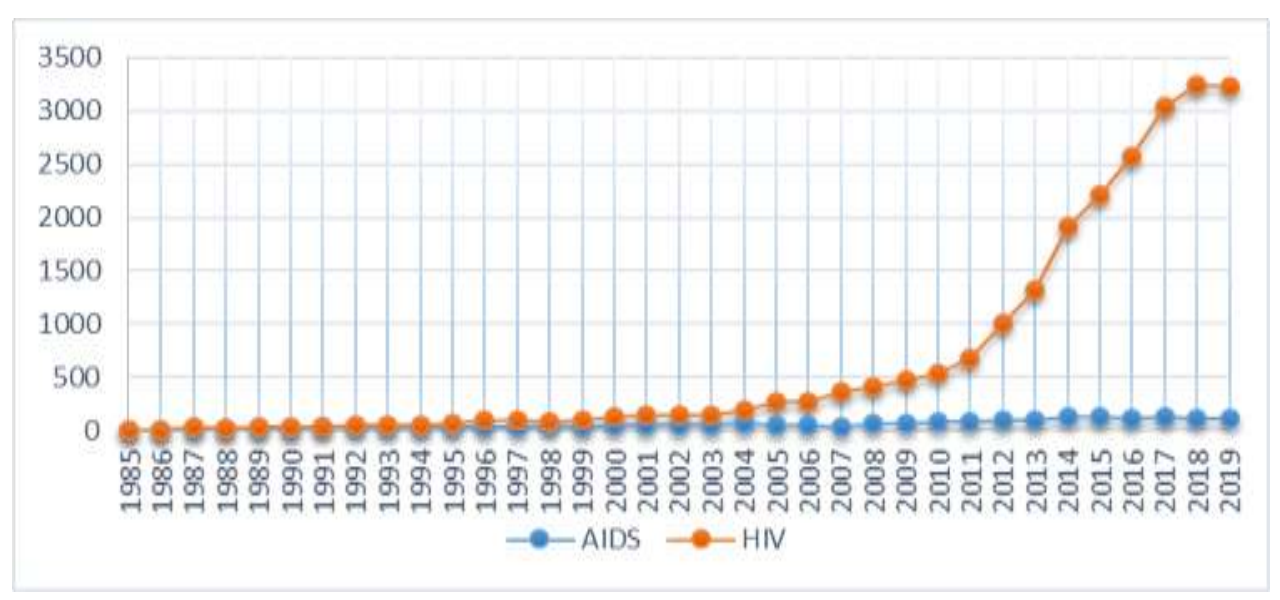

Graph 1. Distribution of Reported HIV/AIDS Cases by Years

When the total HIV/AIDS cases reported to the Ministry of Health between 1985-2019 were examined, the number of cases, which remained horizontal until the beginning of the 2000s, increased rapidly in the following years. 2014 was a year with rapid rises in both HIV (+) and AIDS.

\section{DISCUSSION}

HIV/AIDS is one of the diseases that threaten human life. It is likely to threaten the world population for a long time to come, as there is still no cure. When the course of HIV/AIDS in Turkey is examined, it is seen that the number of cases has increased rapidly from the first case (1985) to 2019. When the trend of the number of cases reported in Turkey is examined, a rapid increase has been observed in the number of cases, which remained horizontal until the 2000s. The number of reported cases after 2014 continued to increase exponentially. When the ten-year average of reported cases is taken, the years with the highest average are between 2010-2019. Although the number of cases in many parts of the world is on a downward trend, the increase in the number of cases in Turkey makes HIV/ AIDS mandatory in terms of disaster management. In the event of a possible epidemic in the society, it has the risk of reaching the size of a disaster by causing great social, economic and health problems.

Countries with a high incidence (more than 20 per 100,000) of newly diagnosed HIV in 2019 are the Russian Federation (54.9), Ukraine (39), the Republic of Moldova (22.8) and Belarus (22.6) (WHO, 2020b).

Newly diagnosed AIDS cases vary widely between countries. The countries with the highest incidence (3 per 100,000 and above) in 2019 are Ukraine (17.9), Republic of Moldova (7.0), Georgia (6.6), Armenia (5.8), Latvia (4.7) and Belarus (4.0). Countries with low incidence (less than 0.3 per 100,000 ) are Slovakia $(0.1)$, Germany (0.1), Ireland (0.1), Bosnia and Herzegovina (0.2) and Poland (0.2). In 2019, there were 0 reported cases in Malta and San Marino. Turkey AIDS data for 2019 includes only those (0.1) who were diagnosed with AIDS at the time of HIV diagnosis (WHO, 2020b).

According to the findings we obtained in our study, HIV/AIDS incidence in Turkey is well below the general average of WHO European Region countries, OCED countries and European Union countries. This situation reveals that Turkey has a lower risk of HIV/AIDS epidemic compared to WHO European Region countries, OCED countries and European Union countries.

Increases in HIV/AIDS cases in East-Central Asia and Eastern Europe are noteworthy. The number of HIV carriers in East Asia increased by $50 \%$ between 2002 and 2004. In this increase, China's contribution to the expanding HIV epidemic seems to be great. A $40 \%$ increase was observed in Eastern Europe and Central Asia. The reason for this increase is the reemergence of the epidemic in Ukraine and the increase in HIV carriers in Russia. The region with the highest HIV epidemic is Sub-Saharan Africa.

In 2009, WHO reported that the AIDS pandemic was declining (Tümer and Ünal, 2016). However, when the 2016 data of the USA is considered, it has been reported that the HIV diagnosis rate is 5.4 per 100,000 for the total population (CDC, 2016). In the data of the study, the HIV diagnosis rate for the same year is approximately 3.21 per 100,000 . This reveals that the incidence of HIV is lower than in the USA.

In Brazil, where the first AIDS case was detected in 1980, more than 900,000 AIDS cases were reported by June 2018. As of 2017, 866,000 people were living with HIV/AIDS. Considering the incidence of HIV in 2017 , this rate is 400 per 100,000 in the general population. While the incidence of AIDS in Brazil was 21.7 per 100,000 in 2012, this 
rate decreased to 18.3 per 100,000 in 2017 (Benzaken at al., 2019). This situation can be considered as positive responses to policy changes of the Department of Sexually Transmitted Diseases (STD), HIV/AIDS and Viral Hepatitis (DIAHV) of the Brazilian Ministry of Health. In the data of our study, the incidence of AIDS in 2016 is approximately 0.1 per 100,000 . This situation shows that the incidence of AIDS in Turkey is lower than in Brazil. In other words, the risk of HIV/AIDS becoming a disaster in Brazil is higher.

According to the European HIV/AIDS Surveillance Report for 2020, HIV continues to spread in countries in the WHO European Region. In 2019, 136,449 new HIV+ cases were reported in the WHO European Region, with a ratio (incidence) of 15.6 per 100,000 population. The number of new AIDS cases in the same year is 12,535 and its ratio (incidence) per 100,000 population is 2 . When the data are examined, the incidence of HIV/AIDS in Turkey remains below the WHO European average.

Since the beginning of the epidemic, 36.3 million (27.2 million-47.8 million) people have died from
AIDS-related diseases. In 2020, there were 37.7 million people living with HIV, of which 36 million were adults. In 2020, about 6.1 million people in the world did not know that they were living with HIV (Web 2,2021).

The population of Turkey has a younger population compared to the European Union countries. While the young population between the ages of $15-24$ is $15.4 \%$ in Turkey, this rate is $10.6 \%$ in the European Union countries (TUIK, 2021). According to the WHO's 2020 report, 1.3 million of the 1.5 million newly diagnosed with HIV constitute the population older than 15 years of age. In the case of the spread of the disease between the ages of $15-24$, it will cause serious workforce losses. This situation may invite social disasters by causing economic damages in the society.

It is stated that the Covid 19 pandemic affects HIV/AIDS patients more. However, no study has been found in Turkey investigating the effects of the Covid 19 pandemic on HIV/AIDS patients.

\section{CONCLUSIONS}

There has been a rapid increase in HIV/AIDS cases in Turkey since the beginning of the 2000s. By 2014 , the increase in the number of cases continued exponentially. While the number of cases in the world has a decreasing curve, there is an increase in Turkey. The young population of Turkey brings the risk of a possible epidemic. HIV/AIDS is not only a health problem, but also a social problem that concerns the whole society and every individual in the society. For this reason, it is important to be informed correctly about the disease, to be conscious, and to learn how to prevent it. Although targets are set for the eradication of HIV/AIDS, it does not seem possible to realize these targets in the near future.

Acknowledgments: None

Conflict of Interest: None

Ethical Approval: The ethics committee permission was not obtained because it was not required.
There is a risk that HIV/ AIDS may become an epidemic in the society and reach the level of disaster. This disaster situation also poses a risk of causing possible secondary social disasters by threatening the young population. All relevant stakeholders should be included in the fight against the epidemic, taking into account the cultural, economic and socioeconomic conditions. HIV/AIDS patients should be included in the risk group for new and reoccurring epidemics. The HIV/AIDS management system needs to be developed in order to be fully aware of the threat posed by the disease and, consequently, to take necessary measures to combat it.

\section{REFE RENCES}

1. Akın, L. (2007). Yeni Görülen Enfeksiyonlar. 11. Ulusal Halk Sağlığı Kongresi Özet Kitabı, Denizli.

2. Güler, Ç., \& Bilgiler, A. L. H. S. T. (2006). Hacettepe Üniversitesi Yayınları. Ankara: ISBN, 248-301.

3. Al-Omari, A., Rabaan, A. A., Salih, S., Al-Tawfiq, J. A., \& Memish, Z. A. (2019). MERS coronavirus outbreak: Implications for emerging viral infections. Diagnostic microbiology and infectious disease, 93(3), 265-285.

4. Babayıgıt, M. A., \& Bakır, B. (2004). HIV enfeksiyonu ve AIDS: Epidemiyoloji ve korunma. TSK Koruyucu Hekimlik Bülteni, 3(11), 280-90.
5. Benzaken, A. S., Pereira, G. F., Costa, L., Tanuri, A., Santos, A. F., \& Soares, M. A. (2019). Antiretroviral treatment, government policy and economy of HIV/AIDS in Brazil: is it time for HIV cure in the country?. AIDS research and therapy, $16(1), 1-7$.

6. CDC, (2016). HIV Survelliance Report Volume 28. February 2018.

https://www.cdc.gov/hiv/pdf/library/reports/surveillance/cdchiv-surveillance-report-2016-vol-28.pdf. (Accessed september 2, 2021).

7. Kaya, N. \& Şahinöz, T. (2021). Bulaşıcı Hastalık Bildirimlerinin Afet Yönetimi Açısından İncelenmesi. Gümüşhane Üniversitesi Sağlık Bilimleri Dergisi, 10 (1), 21 31. DOI: $10.37989 /$ gumussagbil.684067 
8. Merson, ME, Black, RE, and Mills, AJ. (2011). Global health: Diseases, programs, systems and policies. London: Jones \& Bartlett.

9. Moni, M. A., \& Liò, P. (2014). Network-based analysis of comorbidities risk during an infection: SARS and HIV case studies. BMC bioinformatics, 15(1), 1-23.

10. Noë, A., Verhofstede, C., \& Plum, J. (2004). The AIDS epidemic: the spread of a deadly disease in the biotech era. Journal of biological regulators and homeostatic agents, 18(2), 178-182

11. Sheth, A. N., Althoff, K. N., \& Brooks, J. T. (2011). Influenza susceptibility, severity, and shedding in HIV-infected adults: a review of the literature. Clinical Infectious Diseases, 52(2), 219-227.

12. T.C. Ministry of Health. (2004). Bulaşıcı Hastalıkların İhbarı ve Bildirim Sistemi Standart Tanı, Sürveyans ve Laboratuvar Rehberi. Ankara

13. T.C. Ministry of Health. (2019). Türkiye HIV/AIDS Kontrol Programı (2019-2024). Ankara

14. Tümer, A., Ünal, S. (2016). Güncel bilgiler 1şı̆̆ında HIV/AIDS (4. Baskı). Ankara. Bilimsel Tıp Yayınevi.

15. WEB 1. (2021). HIV, HIV/AIDS Basics. https://www.hiv.gov/hiv-basics/overview/about-hiv-andaids/what-are-hiv-and-aids (Acsessed september 1, 2021).

16. WEB 2. (2021). Global HIV \& AIDS statistics - Fact sheet. https://www.unaids.org/en/resources/fact-sheet. (Accessed september 10, 2021).
17. WHO. (2020). HIV/AIDS fact sheet. Geneva: World Health Organization, Available at. https://www.who.int/newsroom/fact-sheets/detail/hiv-aids. (Accessed september 9, 2021).

18. WHO. (2020b). HIV/AIDS surveillance in Europe 2019 data. https://www.ecdc.europa.eu/sites/default/files/documents/hivsurveillance-report-2020.pdf (Accessed september 1, 2021).

19. T.R. Ministry of Health. (2019). Sağlık İstatistikleri Yıllı̆̆ı. https://sbsgm.saglik.gov.tr/Eklenti/40564/0/saglik-istatistikleriyilligi-2019pdf.pdf. (Accessed september 10, 2021).

20. WHO. (2021a). The top 10 causes of death. https://www.who.int/news-room/fact-sheets/detail/the-top-10causes-of-death. (Accessed September 10, 2021).

21. WHO. (2021b). World Health Statistics 2021: Monitoring Health For The Sdgs, Sustainable Development Goals. https://apps.who.int/iris/bitstream/handle/10665/342703/97892 40027053-eng.pdf. (Accessed september 5, 2021)

22. WHO. (2021c). Data on the Size of the HIV/AIDS Epidemic. https://www.who.int/data/gho/data/themes/topics/topicdetails/GHO/data-on-the-size-of-the-hiv-aidsepidemic?lang=en. (Accessed august 25, 2021).

23. Williamson, E. J., Walker, A. J., Bhaskaran, K., Bacon, S., Bates, C., Morton, C. E., ... \& Goldacre, B. (2020). Factors associated with COVID-19-related death using OpenSAFELY. Nature, 584(7821), 430-436.

24. TUIK. (2021). İstatistiklerle Gençlik, 2020. https://data.tuik.gov.tr/Bulten/Index?p=Istatistiklerle-Genclik2020-37242. (Accessed august 28, 2021). 